С. В. Гузенко

\title{
ІНТЕНСИФІКАЦІЯ ВИРАЗНОСТІ СИНТАКСИЧНИХ КОНСТРУКЦІЙ В УКРАЇНСЬКИХ І РОСІЙСЬКИХ РЕКЛАМНИХ ТЕКСТАХ
}

\begin{abstract}
Гузенко С. В. Інтенсифікація виразності синтаксичних конструкцій в українських і російських рекламних текстах.

У статті розглянуто окремі засоби інтенсифікації виразності синтаксичних конструкцій в українських і російських рекламних текстах - компресію викладу і порядок слів. Зроблено висновок про підпорядкованість цих засобів основній прагматичній меті реклами.

Ключові слова: виразність, рекламний текст, порядок слів.
\end{abstract}

Гузенко С. В. Интенсификация выразительности синтаксических конструкций в украинских и русских рекламных текстах.

В статье проанализированы отдельные средства интенсификации выразительности синтаксических конструкций в украинских и русских рекламных текстах - компрессия изложения и порядок слов. Автор делает вывод о подчиненности этих средств главной прагматической цели рекламы.

Ключевые слова: выразительность, рекламный текст, порядок слов.

Guzenko S. V. Intensification of expression of syntactical constructions in the Ukrainian and Russian advertising texts.

In the article the author analyses some means of intensification of expression of syntactical constructions in the Ukrainian and Russian advertising texts - a compression and a word order. The author concludes about subordination of these means of the main advertising pragmatical purpose.

Key words: expression, advertising text, word order.

Проблема виразності мовного знака вже неодноразово привертала увагу дослідників. У роботах здійснено аналіз виражально-зображальних, експресивних засобів мови (української, російської) як стосовно того чи того рівня мовної структури, так і у зв'язку з тими основами, на яких вони постають у різнорідній мовленнєвій практиці людини [6; 7].

Як відомо, рекламні тексти в сучасному мовному середовищі $\epsilon$ одними 3 найбільш експресивних, впливових, емоційних. Аналіз засобів 
виразності на лексичному, морфологічному та синтаксичному рівнях здійснено на матеріалі українських (О. І. Зелінська, С. С. Коваленко), російських (Т. Н. Лівшиць, О. С. Попова, Т. В. Гулак), англійських (М. В. Гусар), іспанських (В. І. Охріменко, Н. Л. Волкогон) рекламних текстів. Недостатньо досліджено засоби інтенсифікації виразності синтаксичних конструкцій у порівняльному аспекті. Проведення такого аналізу на матеріалі українських та російських рекламних текстів і $є$ метою нашої розвідки.

На думку дослідників, виразним, по суті, $є$ будь-який мовний знак, адже така його природа, інакше він не міг би виконувати свою функцію. Інтенсифікація виразності мовного знака відбувається лише в мовленні, під час реалізації комунікативно-інформативних можливостей мовної системи $[6$, c. 7-8]. На синтаксичному рівні розрізняємо інтенсифіковано виразні мовні засоби (стилістичні фігури: еліпсис, повтор, плеоназм, синтаксичний паралелізм тощо) і так звані «інтенсифікатори» виразності (порядок слів, використання певних синтаксичних конструкцій і т. ін.). Усі ці структури занурені у стихію рекламної комунікації і набувають особливої виразності, що сприяє реалізації прагматичної мети реклами - поінформувати про товар чи послугу, вплинути на адресата мовлення - потенційного споживача. Предметом нашого дослідження є інтенсифікатори виразності як малодосліджені елементи.

У рекламних текстах компресія, редукція висловлювань насамперед формують виразність синтаксичних структур. Талановиті автори цих текстів максимально мінімізують їх, виокремлюючи таким чином найголовнішу інформацію. На синтаксичному рівні це реалізується завдяки використанню простих двоскладних непоширених речень: Акция началась! [МПС, 2011, № 3, с. 2]; Мрї здійснюються! [МТ, 2006, № 1, c. 107]; речень-дефініцій із лексично вираженим іменним складеним присудком. У такі «визначення» включено не звичайні ознаки (хай навіть і яскраві), а ознаки істотні, які можна виявити і сформулювати лише внаслідок дослідження й узагальнення. Отже, довіра до таких структур є набагато вищою, ніж до інших речень: ІНВЕСТИЦІЇ-найкоротший шлях до ycnixy [К., 2004, № 22, с. 17]; «Cynер BUSINESS life»-найвигідніший тариф на ринку мобільного зв’язку [Б., 2007, № 6, с. 9]; Правильный выбор для любой дорожной ситуации - Программа BILSTEI [3Р, 2011, № 5, с. 73].

Автор компресує виклад матеріалу й одночасно повідомляє різноманітну суттєву інформацію за допомогою використання конструкцій 3 однорідними членами речення: ГРУПА САНАТОРЇ̈В ПРОПОНУС: комплексне санаторно-курортне лікування, готельне розмімення, спеціальні лікувальні програми [МТ, 2007, № 2, с. 79]; Вона [туристична програма] розповідає про далекі краї та заморські дива, дарує приємні сюрпризи, дає цінні поради мандрівникам [MT, 2006, № 1, с. 87]; Высококачественные серийные амортизаторы, мощуные амортизаторы для внедорожников, комплекты подвески для тюнинга и автоспорта: с 
таким ассортиментом BILSTEIN каждый сможет полностью реализовать свои водительские амбиции и получить безграничное удовольствие от вождения [3Р, № 5, 2011, с. 73].

Частотним для рекламних текстів $\epsilon$ використання різних видів односкладних речень. Зміст у таких конструкціях передано сконденсовано, виразно. Їхньою прагматичною основою $\epsilon$ вираження прохання, наказу, побажання і т. ін. Найпростішими мовними засобами, за допомогою яких маніфестується воля людини, $\epsilon$ односкладні означено-особові та узагальнено-особові речення із головним членом - дієсловом наказового способу: Підключайтесь до тарифу «Вільний life:). Розмовляйте з усіма абонентами life:) по 0 коп./хв. Зберіть команду з 5-ти учасників та отримайте бонус 50 грн щзомісяияя до 2008 року! [От., 2007, № 6, с. 7]; Летайте Эмирейтс из Москвы и Санкт-Петербурга по всему миру через Дубай [GEO, 2011, № 9, с. 13].

Використання означено-особових конструкцій може також акцентувати передання семантики гарантування: Печатаем... 200 листов в минуту. Формируем, фальиуем, проклеиваем и перфорируем бесконвертные отправления. Укладываем 4000 конвертов в час. Отправляем с почтальонами письма с конвертами и без Вашим любимым адресатам. Печатаем адреса на любых конвертах [ДС, 2010, № 11, с. 28].

Продуктивним i виразним у рекламних текстах $\epsilon$ використання односкладних номінативних речень. Їхньою основною стилістичною функцією є ствердження буття рекламованих предметів чи послуг, їх виділення, а також звичайне найменування. Залежно від значення та структури в рекламних текстах представлені такі види номінативних речень:

1. Буттєві («Нові автомобілі. Продаж. Гарантія. Сервіс. Кредит до 4-х років» [К., 2004, № 4, с. 51].

2. Оцінні. Такі речення поєднують у собі номінацію предмета та його емоційну оцінку. Причому таку оцінку передано імпліцитно за допомогою окличного речення, в якому сконденсовано емоційно-експресивне забарвлення, передано «захоплення» автора рекламованим товаром: Перший в Свроni! Six Senses Spa! [MT, 2007, № 3, c. 53]; Весь Мир. Каждый день [GEO, 2011, № 9, с. 13].

3. Номінативні теми. А. П. Загнітко кваліфікуе цей різновид як речення, оскільки «він являє собою інтонаційно самостійну комунікативну одиницю - через неї мовець повідомляє про наявність у свідомості уявлення і викликає аналогічну асоціацію у свідомості співрозмовника» [3, с. 169]. У рекламних текстах такі речення часто $є$ заголовками, вони називають рекламований предмет, який буде представлений далі в основному тексті. Наприклад, Квітка Безсмертника [MT, 2007, № 3, с. 5].

Як відомо, номінативні речення із загальною стилістичною семантикою виділення можуть використовуватися для виокремлення у художньому стилі і відтворення особливостей структурно- 
інтонаційного увиразнення розмовного стилю [2, с. 73]. Номінативні речення порівняно $з$ двоскладними є стислішими, надають експресивного характеру вислову, передають окремі не об'єднані між собою деталі [1, с. 12]. Лаконічність цих структур у рекламних текстах впливає на стилістичну виразність, підвищує інформативність тексту загалом. Крім того, в таких реченнях може бути сформульовано головний мотив купівлі товару. А мотив завжди $€$ поштовхом для здійснення дії через усвідомлення нової потреби, наприклад: Довірений водій. Абсолютний комфорт. Безпека (реклама автомобілів) [Б., 2004, № 10, с. 142].

Ще одним засобом інтенсифікації виразності синтаксичних конструкцій є порядок слів, що допомагає упорядкувати зміст, зробити певні акценти. Як відомо, найбільш запам'ятовуються ті частини висловлення, що знаходяться або на його початку, або наприкінці. У рекламі таким маркованим елементом є назва рекламованого об'єкта у функції підмета (іноді додатка), що часто винесена на початок речення, наприклад: Chrysler 300M - стильний спортивний седан, щзо об'єднує найкращі ходові характеристики, американську практичність та оригінальний дизайн [К., 2004, № 11, с. 59]; ЮРИДИЧНА ФІРМА «СТОЛИЧНИЙ АДВОКАТ» надасть усні консультаиії та письмові юридичні висновки з правових питань, підготує документи... [Б., 2004, № 10, с. 145]; «Шанс.Model.иа» - сльози щастя та радість перемоги. «Шанс.Model.иа» - найпрестижнімі знімальні майданчики та подіуми. «Шанс.Model.ua» - ие шанс кардинально змінити своє життя на краще [К., 2004, № 33-34, обкл. 3]; КYВ - крупнейший поставщик амортизаторов на конвейер $и$ один из ведущих поставщиков амортизаторов на вторичный рынок (aftermarket) Европьы. КYВ доверяют ведущие мировые производители автомобилей... [3Р, 2011, № 5, с. 121].

На думку адресантів реклами, використання рекламованого товару потенційним споживачем $\epsilon$ причиною покращення якості життя останнього. Саме тому в сильну початкову позицію виносять назву об'єкта реклами із прийменниками за допомогою (укр.), із (укр.), благодаря (рос.), наприклад: За допомогою функиї «Подорож у часі» Ви можете швидко та легко настроїти запис на потрібний Вам час [Б., 2007, № 3-4, обкл. 4]; Із новим тарифом Ви можете вирімувати свої ділові питання, не звертаючи уваги на тривалість розмови [Б., 2007, № 6, с. 9]; Благодаря передовым техническим решениям фильтры Mann-Filter показывают максимум эффективности и сохраняют свои качества в течение всего срока эксплуатаџии даже в критических режимах [3Р, 2011, № 5, с. 19]. Такі конструкції допомагають підкреслити значення вигоди адресата, здійснюючи таким чином додатковий вплив на потенційного споживача.

У спонукальних реченнях рекламних текстів звертає на себе увагу на початку речення присудок, виражений дієсловом наказового способу. Саме на ці слова падає логічний наголос. Така синтаксична структура разом із 
чіткою ритмічною організацією висловлень сприяє загальному увиразненню рекламних текстів, побудові механізму наступних дій адресата, наприклад: Вмикай та слухай «Ранок на сніданок» по буднях $з$ 6:00 до 10:00 [В., 2008, червень, с. 11]; Читайте y n'ятницяю в журналі «Тернопільський оглядач» [ТО, 2008, 09.04]; Не мечтай. Действуй [GEО, 2011, № 9, с. 17]. У сильну початкову позицію може бути винесена пропозиція адресатові здійснити очікувану дію, пов’язану з використанням рекламованого товару: Куnи, Слухай, Придбай та ін., або ж таку дію, яка повинна привести до результату, слабо пов'язаного із рекламованим товаром: реалізації мрії, покращення життя, наприклад, Використай свій шанс. Створи власну епоху! (реклама меблів) [МТ, 2007, № 3, с. 37]; Уяви тонкощъі бізнесу! (реклама мобільного телефону) [Б., 2007, № 3-4, с. 27]; Увійдіть у світ привілеїв (реклама кредитних карток) [Б., 2007, № 3-4, с. 13]; Спіймай час! Володій світом! (реклама телевізорів) [Б., 2007, № 3-4, обкл. 4]; Наслаждайтесь (реклама туристичних послуг) [Discovery, 2011, № 4, с. 41]; Заявите всему миру о себе! (реклама студії веб-дизайну) [ДС, 2010, № 12, с. 25]. Таке пряме спонукання до дії не сприймається як насильство через те, що має вигляд гедоністичної спокуси [4].

На початок речення може бути винесено підмет, виражений особовим займенником ми. Як правило, ці речення побудовані за структурною схемою: $\mathrm{S}$ - V, де $\mathrm{S}$ - суб'єкт - адресант мовлення, а V предикат - має семантику гарантування обіцянки, наприклад: ...Mu уміємо якісно $і$ швидко виконувати таку роботу: обстежувати будівельні конструкиї, визначати дефекти залізобетонних елементів, герметизувати силосні сховищза... [3. і Х., 2006, № 2, с. 55]; Ми вміємо проривати інформаційну блокаду і маємо відповідний досвід... Ми справді незалежні і водночас прагматичні... [П. і Ч., 2006, № 12, с. 60]; Mы Вам в этом поможем! (реклама студії веб-дизайну) [ДС, 2010, № 12, с. 25].

У центрі уваги реклами завжди знаходиться адресат - потенційний споживач, з його потребами і бажаннями. Підмет, виражений особовими займенниками $m u$, ви, часто винесено в сильну початкову позицію: $B u$ одразу зможете користуватися кредитною лінією [Б., 2007, № 1-2, с. 51-52]; Ви можете міняти адресу офісу - номер завжди буде за вами [Б., 2007, № 3-4, с. 11]; Bы почувствуете уникальность комбинации современных технологий автоспорта и оригинального качества поставщика на конвейер [3Р, 2011, № 5, с. 73]. Підкреслює повагу до адресата означення, виражене займенником Ваш, у початковій позиції, наприклад: Ваше посвідчення - це вибір легендарної якості Nissan. Bam привілей - престижні моделі на ексклюзивних умовах [Б., 2007, № 3-4, с. 13]; Ваша выгода у нас в Приоритете [GEO, 2011, № 9, с. 9].

Іноді в рекламних текстах створено атмосферу таємничості, загадковості з метою заінтригувати адресата, привернути увагу до тексту. В таких текстах навіть може не бути вербалізовано назву рекламованого 
об'єкта, яка, як правило, є в невербальній частині (на зображенні або у формі логотипа). Збільшує виразність таких текстів використання у ролі підмета особового займенника він (он) у початковій позиції, наприклад: Він втілюе динаміку та елегантність, притаманні всім моделям Пежо. Він красивий та безпечний, що є фірмовим стилем Пежо. Але він не схожий на своїх попередників [К., 2004, № 38, с. 17]; Он без усилий поглощает километры. Грациозно движется сквозь 70-сантиметровую толщу воды. Легко проглатывает всё Ваше подводное снаряжение...(реклама автомобіля) [GEO, 2011, № 9, с. 2].

Ще одним засобом інтенсифікації виразності є мовні контрасти. На синтаксичному рівні вони виявляють себе в різноманітних протиставленнях: часових (раніше - тепер), суб'єктних (ми - інші), об'єктних (наша продукція - товари інших виробників). Як правило, ці протиставлення також винесені у сильну початкову позицію, що привертає додаткову увагу адресата: Biдтепер Вам можуть телефонувати за тарифами звичайного міського [Б., 2007, № 3-4, с. 11]; Раніше я про ие не думав. ТЕПЕР Я ЗНАЮ [Контракти, 2004, № 20, с. 7]; Mbl сделали кондииионер. Другие так не могут [Discovery, 2011, № 4, c. 95].

Своєрідною формою збільшення виразності є питальні речення. Так, у запитаннях може бути сформульовано гіпотетичну проблему адресата. У такому разі з нього розпочинається текст, а основний текст містить відповідь-інформацію про розв'язання проблеми адресата завдяки рекламованому товару, як-от, наприклад, у заголовках: А Ви подбали про безпеку своїх працівників? [ДМ, 2008, 22.05]; Бажаєте придбати шини дешевше? [К., 2004, № 5, с. 53]; Ви отримали компенсачію за ощадкнижкою? [ДМ, 2008, 22.05]; A какие фильтры используете Bы? [3Р, 2011, № 5, c. 19].

Цікаво, що «вмонтовані питання співвіднесені з вмонтованими командами» [5, с. 204]. У цих реченнях формулюється можлива потреба мотив придбання товару, а специфіка сучасного рекламного дискурсу в умовах конкуренції полягає в тому, що нав'язується, навіюється адресатові не тільки товар, а й потреба його споживання. До того ж конструкції «запитання - відповідь» наближають мову реклами до розмовного стилю, що увиразнює іiі, робить експресивною.

Отже, розглянуті інтенсифікатори виразності синтаксичних конструкцій - компресія викладу і порядок слів - свідчать про схожість використання цих прийомів в українській та російській мовах. Скорочення тексту дає можливість адресату «домислити» його, що активізує мисленнєву активність читача, сприяє запам'ятовуванню. Винесення у початкову позицію наважливішої інформації привертає увагу адресата, виконує контактовстановлюючу функцію. Основною причиною використання цих засобів у рекламних текстах $є$ реалізація прагматичної мети реклами - здійснення впливу на потенційного споживача. 


\section{Література}

1. Біятенко Л. О. Стилістичне використання номінативних речень / Л. О. Біятенко // Українська мова в школі. - 1962. - № 6. - С. 11-13.

2. Срмоленко С. Я. Синтаксис і стилістична семантика / С. Я. Срмоленко. - К. : Наукова думка, 1982. -209 c.

3. Загнітко А. П. Український синтаксис: науково-теоретичний і навчально-практичний комплекс : навч. посібник / Інститут змісту і методів навчання ; Донецький держ. ун-т. - К. : ІЗМН, 1996. - Ч. 1. - 202 с.

4. Павлюк Л. Г. Аксіологічні та структурні характеристики дискурсу реклами у мас-медіа [Електронний ресурс] / Л. Г. Павлюк// Наукові записки Інституту журналістики. - Том 22. Режим доступу до журн.: http://journlib.univ.kiev.ua/index.php?act=article\&article=1460.

5. Ковалевська Т. Ю. Комунікативні аспекти нейролінгвістичного програмування : монографія / Т. Ю. Ковалевська. - Одеса : Астропринт, 2008. - 324 с.

6. Чабаненко В. А. Стилістика експресивних засобів української мови / В. А. Чабаненко ; Запорізький держ. ун-т. - Запоріжжя, 2002. - 351 с.

7. Человеческий фактор в языке: Языковые механизмы экспрессивности / Ин-т языкознания ; отв. ред. В. Н. Телия. - М. : Наука, 1991. - 214 с.

Б. - Бізнес

В. - Вона

ДМ - Ділове місто

ДС - Деловой статус

3. і Х. - Зерно і хліб

ЗР - За рулем

\section{Список умовних скорочень}
К. - Контракти
МПС - Мой прекрасный сад
МТ - Міжнародний туризм
От. - Отдохни
П. і Ч. - Політика і час
ТО - Тернопільські оголошення 